\title{
Distribution of EGFR R521K Polymorphism in Different Iranian Ethnic Groups
}

\author{
Asal Shahrokhshahi, ${ }^{1}$ and Massoud Houshmand ${ }^{2,}$ \\ ${ }^{1}$ Department of Molecular and Cellular Sciences, Faculty of Advanced Sciences and Technology, Pharmaceutical Sciences Branch, Islamic Azad University, Tehran, IR Iran \\ ${ }^{2}$ Department of Medical Genetics, National Institute of Genetic Engineering and Biotechnology, Tehran, IR Iran \\ "Corresponding author: Massoud Houshmand, Department of Medical Genetics, National Institute of Genetic Engineering and Biotechnology, Tehran, IR Iran. E-mail: \\ massoudh@nigeb.ac.ir
}

Received 2015 September 29; Accepted 2015 December 12.

\begin{abstract}
Background: The R521K polymorphism of EGFR has attenuated function in ligand binding, tyrosine kinase activation, and growth stimulation.

Objectives: We initiated a study to examine R521K polymorphism in six Iranian ethnic groups.

Patients and Methods: This cohort study was designed on 300 Iranian healthy individuals and analyzed by PCR-RFLP protocol.

Results: The frequencies of A/A, G/A, G/G genotype were 7.7\%, 53.6\% and 38.7\% respectively.

Conclusions: No subject with A/A genotype was detected in Kurds and Lures. The higher frequencies of A/A genotype in Arab and Caspian groups compared to Fars and Turks could be a key determinant of better response to anticancer drugs and favorable prognosis of CRC patients.
\end{abstract}

Keywords: Colorectal Cancer, Epidermal Growth Factor Receptor, R521K Polymorphism, Iranian Ethnic Groups

\section{Background}

Colorectal cancer (CRC) is one of the most frequent cause of cancer mortality in Iran $[1,2]$. The relationship between dietary, environments factors, the age of over 50 , genetic risk factor and CRC has been evaluated [3, 4].

The discovery of epidermal growth factor receptor (EGFR) in the process of cell proliferation has produced an exciting era in the treatment of CRC.

Epidermal growth factor receptor is a transmembrane glycoprotein of $170 \mathrm{KD}$ encoded by a gene located in the short arm of chromosome 7 (chromosome 7 P 12.1-12.3) [5].

After binding a ligand the receptor dimerizes and that event leads to auto phosphorylation followed by recruitment and phosphorylation of many intracellular substrates [6]. This chain of phosphorylation leads to activation of several signaling pathway such as Ras/Raf/MAPK or phosphatidylinositol-3-kinase(PI3K) that are involved in cell growth, cell proliferation angiogenesis and inhibition of apoptosis [7, 8].

Blocking EGFR ligand binding with therapeutic monoclonal antibodies have been shown to be an effective treatment for CRC [9].

$\mathrm{R} 521 \mathrm{~K}$ is functional polymorphism in EGFR that arose from a $G$ to A transition, resulting in an Arg to Lys substitution [10].

Compared with the wild type 521R allele, the lysine allele variant has attenuated affinity in ligand binding, tyrosine kinase activation and induction of the protooncogenes Myc, Fos and Jun [11].

\section{Objectives}

This study aims to investigate allele frequencies of the polymorphism R521K in EGFR found in different ethnic groups of Iranian population that could be associated with a better outcome in CRC patients.

\section{Patients and Methods}

This cohort study was conducted in 300 healthy Iranian subjects and of the different ethnicity (169 Fars, 77 Turks, 13 Kurds, 17 Lures, 12 Arabs and 12 Caspian groups). Genomic DNA was extracted from peripheral blood lymphocyte using DNA purification kit (Tehran, Iran) extraction. The $\mathrm{R} 521 \mathrm{~K}(\mathrm{G}<\mathrm{A})$ polymorphism in exon 13 of epidermal growth factor receptor (EGFR) gene was examined by as PCR-RFLP method as described previously [8]. The PCR primers were $5^{\prime}$-TGCTGTGACCCACTCTGTCT-3' (forward) and $5^{\prime}$-CCAGAAGGTTGCACTGT- $3^{\prime}$ (reverse). The PCR reactions were performed in a total volume of $25 \mu \mathrm{M}$, containing $150 \mathrm{ng}$ genomic DNA, $0.8 \mu \mathrm{M}$ of each primer 2.5 $\mu \mathrm{M}$ PCR buffer, $0.5 \mu \mathrm{M}$ dNTPs, $0.8 \mu \mathrm{M} \mathrm{MgCl}_{2}, 2.5 \mu \mathrm{M}$ DMSO 
(Dimethyl sulfoxide) $1 \mathrm{X}$ Taq buffer and 1 unit of Taq DNA polymerase. The PCR cycle conditions of an initial denaturation at $94^{\circ} \mathrm{C}$ for 4 minutes, followed by 32 cycle of $94^{\circ} \mathrm{C}$ for 50 second, $59.4^{\circ} \mathrm{C}$ for 50 second, $72^{\circ} \mathrm{C}$ for 50 second and final extension at $72^{\circ} \mathrm{C}$ for 10 minutes. The $155 \mathrm{bp}$ PCR product was digested overnight with Mva1 restriction enzyme at $37^{\circ} \mathrm{C}$ and alleles were separated on polyacrylamide gels and visualized under ultraviolet (UV) light.

The expected restriction fragments were:

$\mathrm{G} / \mathrm{G}=38 \mathrm{bp}+50 \mathrm{bp}+67 \mathrm{bp}$

$\mathrm{G} / \mathrm{A}=38 \mathrm{bp}+50 \mathrm{bp}+67 \mathrm{bp}+117 \mathrm{bp}$

$\mathrm{A} / \mathrm{A}=38 \mathrm{bp}+117 \mathrm{bp}$

All data analyses were carried out using SPSS-13 statistical software. P values $<0.05$ were considered statistically significant.

\section{Results}

The genotype distributions were in Hardy-Weinberg equilibrium. A total 300 subjects, $38.6 \%$ were homozygous or Arg/Arg variant (normal genotype), 53.6\% were heterozygous that having both the alleles (Arg/Lys) and 7.6\% were homozygous for Lys/Lys genotype (mutant genotype).

The results of $\mathrm{R} 521 \mathrm{~K}$ genotype distribution in different ethnic groups of Iranian population are summarized in Table 1. In this study, we found that $\mathrm{G} / \mathrm{G}$ and $\mathrm{G} / \mathrm{A}$ genotype were detected in all six ethnic groups, we did not find any A/A genotype (mutant type) In Kurdes and Lures.

Figure 1. PCR Products After Being Digested by Mva1 Were Separated by Polyacrylamide Gel Electrophoresis

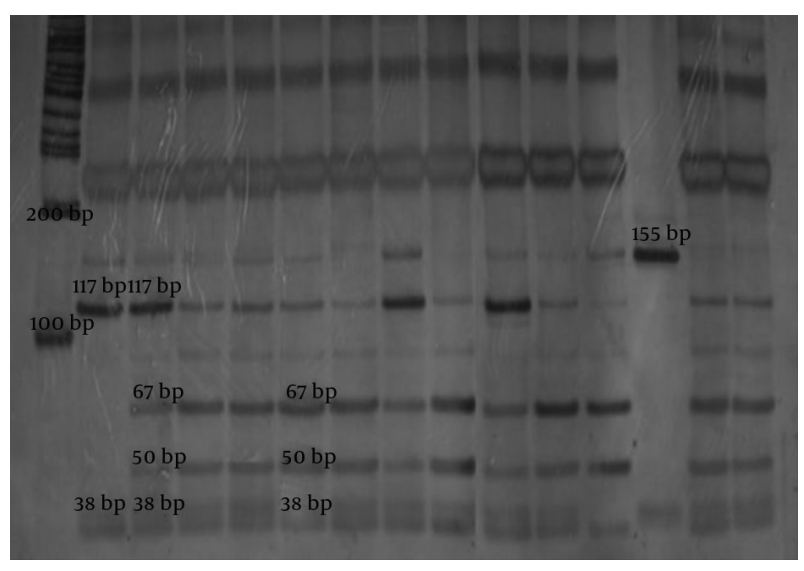

Lane 1 in 100 bp DNA ladder; Lane 2 is homozygous genotype Lys/Lys with two bands 38, $117 \mathrm{bp}$; Lane 3, 8 are heterozygous genotype Arg/Lys showing four bands 38, 50, 67, 118; Lane 4, 5, 6, 7 are homozygous genotype Arg/Arg showing three bands 38, 50, 67 bp.

\section{Discussion}

We examined six Iranian ethnic groups for the prevalence of R521K polymorphism in 300 healthy subjects, including Fars, Turks, Kurds, Lures, Arabs and Caspian groups. Heterozygous (G/A) is the most common genotype in five ethnic groups, although GG genotype is predominant allele and occurred in high frequencies in Arab ethnic groups. From this study, we conclude that GA and GG genotype found in all six ethnic groups. AA was not detected in Kurds and Lures but was found among the Fars, Turk, Arabs and Caspian groups. The frequency of AA allelic variant appeared to be lower in Fars and Turks compared to Arabs and Caspian groups.

A polymorphic variant EGFR arising from single nucleotide change $(G>A)$ leading to arginine $(R)$ to lysine (K) substitution in codon 521 in the extracellular domain of EGFR has been identified.

EGFR + 521 A/A genotype confers an attenuated function in EGFR ligand binding, growth stimulation, tyrosine kinase activation and induction of proto-oncogenes. Moreover, A/A genotype was associated with poor clinical outcome and shorter PFS (Progression free survival) compared with other genotypes [11,12].

The R521K EGFR polymorphism correlates with a decrease in EGFR phosphorylation, decrease invasion, lower nodal involvement, reduce subsequent metastasis and longer disease-free and overall survival in stage II/III colorectal carcinoma patients who have received curative surgery $[13,14]$.

According to SNP database, A/A genotype (mutant type) frequency was less when compared with East Asian, but remarkably higher than that African-American and SubSahara Africans population. We not observed significant differences with the most European populations.

Based on finding that A/A genotype of R521K EGFR polymorphism influence the efficacy of anticancer drugs and its associated with increased response to monoclonal antibodies by reducing its activation and consequential down regulation of its target gene, our results suggest that Kurds and Lures may predict sub-optimal rates of clinical response to monoclonal antibodies. The higher frequencies of A/A genotype in Arabs and Caspian groups compared with Fars and Turks, it appears that the use of monoclonal antibodies might produce good outcome and favorable prognosis in these groups of Iranian CRC patients.

\section{Acknowledgments}

This paper is based on the author's thesis (Asal, Shahrokhshahi, code number: A21) with Dr Houshmand. 
Table 1. R521K Genotype Distribution in Different Ethnic Groups of Iranian Population ${ }^{\mathrm{a}}$

\begin{tabular}{|c|c|c|c|}
\hline Ethnicity & $\mathbf{A} / \mathbf{A}$ & $\mathbf{G} / \mathbf{A}$ & G/G \\
\hline Fars & 8.3 & 51.5 & 40.2 \\
\hline Turk & 6.5 & 58.44 & 35.06 \\
\hline Kurd & 0 & 53.85 & 46.15 \\
\hline Lure & 0 & 70.59 & 29.41 \\
\hline Arab & 16.67 & 33.33 & 50 \\
\hline Caspian & 16.67 & 50 & 33.33 \\
\hline
\end{tabular}

${ }^{\mathrm{a}}$ Values are expressed as percentage.

\section{Footnotes}

Authors' Contribution: Asal Shahrokhshahi, gathering data, review and writing; Massoud Houshmand, review and editing.

Funding/Support: Islamic Azad University, Tehran.

\section{References}

1. Moghimi-Dehkordi B, Safaee A, Zali MR. Prognostic factors in 1,138 Iranian colorectal cancer patients. Int J Colorectal Dis. 2008;23(7):683-8. doi: 10.1007/s00384-008-0463-7. [PubMed: 18330578].

2. Kolahdoozan S, Sadjadi A, Radmard AR, Khademi H. Five common cancers in Iran. Arch Iran Med. 2010;13(2):143-6. [PubMed: 20187669].

3. Satia-Abouta J, Galanko JA, Potter JD, Ammerman A, Martin CF, Sandler RS, et al. Associations of total energy and macronutrients with colon cancer risk in African Americans and Whites: results from the North Carolina colon cancer study. Am J Epidemiol. 2003;158(10):95162. [PubMed: 14607803].

4. Haggar FA, Boushey RP. Colorectal cancer epidemiology: incidence, mortality, survival, and risk factors. Clin Colon Rectal Surg. 2009;22(4):191-7. doi: 10.1055/s-0029-1242458. [PubMed: 21037809].

5. Davies RL, Grosse VA, Kucherlapati R, Bothwell M. Genetic analysis of epidermal growth factor action: assignment of human epidermal growth factor receptor gene to chromosome 7. Proc Natl Acad Sci U S A. 1980;77(7):4188-92. [PubMed: 6254014].

6. Franklin WA, Veve R, Hirsch FR, Helfrich BA, Bunn PJ. Epidermal growth factor receptor family in lung cancer and premalignancy. Semin Oncol. 2002;29(1 Suppl 4):3-14. [PubMed: 11894009].
7. Citri A, Yarden Y. EGF-ERBB signalling: towards the systems level. Nat Rev Mol Cell Biol. 2006;7(7):505-16. doi: 10.1038/nrm1962. [PubMed: 16829981].

8. Ciardiello F, Tortora G. EGFR antagonists in cancer treatment. $N$ Engl J Med. 2008;358(11):1160-74. doi: 10.1056/NEJMra0707704. [PubMed: 18337605].

9. Sato JD, Kawamoto T, Le AD, Mendelsohn J, Polikoff J, Sato GH. Biological effects in vitro of monoclonal antibodies to human epidermal growth factor receptors. Mol Biol Med. 1983;1(5):511-29. [PubMed: 6094961].

10. Moriai T, Kobrin MS, Korc M. Cloning of a variant epidermal growth factor receptor. Biochem Biophys Res Commun. 1993;191(3):1034-9. doi: 10.1006/bbrc.1993.1321. [PubMed: 8466482].

11. Moriai T, Kobrin MS, Hope C, Speck L, Korc M. A variant epidermal growth factor receptor exhibits altered type alpha transforming growth factor binding and transmembrane signaling. Proc Natl Acad Sci U S A. 1994;91(21):10217-21. [PubMed: 7937865].

12. Lurje G, Nagashima F, Zhang W, Yang D, Chang HM, Gordon MA, et al. Polymorphisms in cyclooxygenase-2 and epidermal growth factor receptor are associated with progression-free survival independent of K-ras in metastatic colorectal cancer patients treated with single-agent cetuximab. Clin Cancer Res. 2008;14(23):7884-95. doi: 10.1158/1078-0432.CCR-07-5165. [PubMed: 19047118].

13. Wang WS, Chen PM, Chiou TJ, Liu JH, Lin JK, Lin TC, et al. Epidermal growth factor receptor R497K polymorphism is a favorable prognostic factor for patients with colorectal carcinoma. Clin Cancer Res. 2007;13(12):3597-604. doi: 10.1158/1078-0432.CCR-06-2601. [PubMed: 17575224].

14. Hsieh YY, Tzeng $\mathrm{CH}$, Chen MH, Chen PM, Wang WS. Epidermal growth factor receptor $\mathrm{R} 521 \mathrm{~K}$ polymorphism shows favorable outcomes in KRAS wild-type colorectal cancer patients treated with cetuximabbased chemotherapy. Cancer Sci. 2012;103(4):791-6. doi: 10.1111/j.13497006.2012.02225.x. [PubMed: 22321154]. 